\title{
Environmental risk management of urban growth poles regarding national importance
}

\author{
${ }^{1}$ *D. Peptenatu; ${ }^{2}$ R. D. Pintilii; ${ }^{2}$ C. Draghici \\ ${ }^{I}$ Department of Human and Economic Geography and Researcher at the Interdisciplinary Center for Advanced \\ Researches on Territorial Dynamics, University of Bucharest, Romania \\ ${ }^{2}$ The Interdisciplinary Center for Advanced Researches on Territorial Dynamics, University of Bucharest, Romania \\ Received 2 August 2010; $\quad$ revised 2 October 2010; accepted 21 July 2011
}

\begin{abstract}
Urban settlements of regional importance from Romania impose within the national settlements system by their ability to converge material and human flows, leading to important unbalances in the relationships between the components of territorial systems. The status they held, both in the communist period and at present, made the economic activities developed in a short time exceed the adapting ability of the other components of the territorial system, the natural environment strongly feeling the industrialisation pressure. Identifying the specificities of the environmental risk management at the level of development poles of regional importance was done by detailed analyses accomplished in Craiova, a representative town for the high concentration of economic activities strongly pressing upon the natural environment. The construction of the model of environmental risk management supposes the classifying of risks by a series of criteria, a model which constitutes a useful instrument for the decision factors. The management of unbalances from the territorial systems determined by industrialisation is one of the major preoccupations of the decision factors from Romania, in order to be aligned to the European environment standards.
\end{abstract}

Keywords: Industrial pressure; Local communities; Pollution; Polycentric network; Sustainable development

\section{INTRODUCTION}

Human settlements of regional importance impose in the national settlements system by their ability to promote information which is indispensable for the development within the settlements network they coordinate, as well as by the capacity to converge material and human flows (Ianos, 2000).

This category of settlements comprises towns of over 300.000 inhabitants, with high concentrations of economic activities, predominantly industrial and human flows (the population weight after 1990 was over $5 \%$ for each one), this exerting a high pressure upon the natural and social environment (Tehrani et al., 2009; 2010). The responsible approach for the environment problems is an important task of the decision factors, in the complex process of elaborating the integrated development directions of the urban settlements of regional level (Ianos et al., 2009; Gavrilescu, 2009; Robu and Macoveanu, 2009). The efficency of the management strategies is conditioned

*Corresponding Author Email: pinty_rd@yahoo.com Tel./ Fax: +40788990060 by the complex approaches of imbalances between parts of the territorial system, by complex analyses methodologies. (Beer, 2006). One of the indispensable methodologies of integrated approaches of environmental risk is the geographical informational systems that permits a superior modeling of territorial reality. The concentration of economic activities and these towns' importance within the regional polycentric networks oblige the decision factors to elaborate efficient management strategies of environmental risk, their specificity being determined by the contradictory dynamic of these territorial systems after 1990.

In Romania, except the capital Bucharest, there are seven towns with over 300.000 inhabitants (Craiova, Timisoara, Cluj-Napoca, Constanpa, Iasi, Galati, Brasov) (Fig. 1), representing nuclei of coordinating some human settlements networks, where they have the role of transmitting information which is indispensable for development. The high concentration of economic activities determines, on the one hand, a high pressure upon natural environment, and on the 


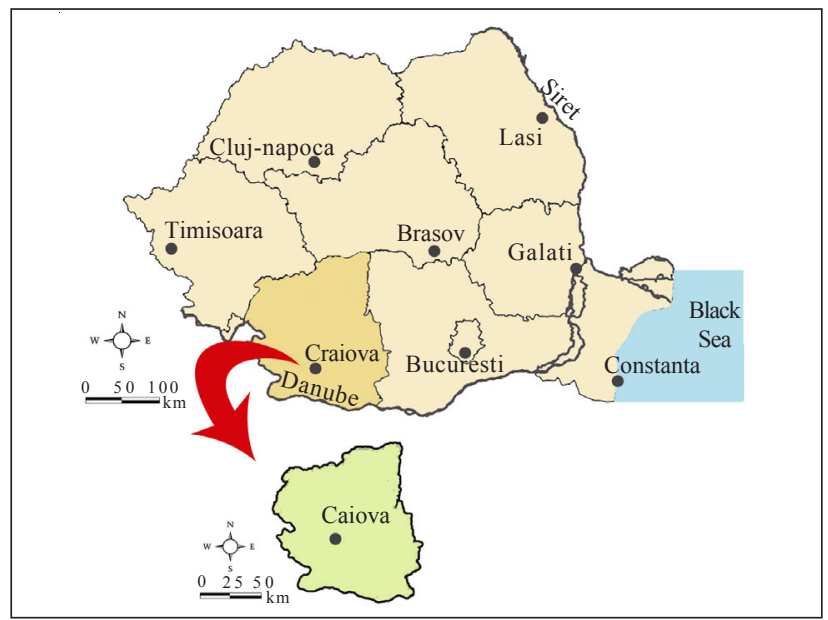

Fig. 1: Distribution of main national development poles in Romania

other hand some specific measures of managing the functional unbalances from the territorial systems components' level. The six towns have got a similar evolution, some massive investments being necessary in the communist period, when Romania's most important industrial platforms were set up.

Environmental risk is the result of the interaction of the two major components of territorial systems: the environment component and the human component, which are displayed as major functional unbalances, endangering achievement of development objectives (Chien and Shih, 2007; Choi and Lee, 2009; Braghina et al., 2010). Environmental risk management suppose a superior level of perception of the importance to anticipate the relationships dysfunctions between natural and environmental dimension (Ianos et al., 2009).

The strategic dimension of the environmental risk management supposes to identify the way the development objectives of territorial systems may be affected (Pollack, 1994; Hooghe and Marks, 2001).

Environmental risk management shows a series of particularities due to the complexity of the environments affected by the concentration of human activities, a complexity which determines numerous uncertainties (Babut and Moraru, 2006; Nouri et al., 2011).

The construction of the environmental risk management models must take into account the amplitude of the existent and potential unbalances (Fekete, 2006; Ianos et al., 2009), their efficiency being strictly connected to the community's participation by informing and consulting in all the stages of the implementation process (Szigethy, 2007).
The research activities have been conducted in Craiova, an important pole of development of Romania, representative of imbalances between the relationships of the environment and the economic activities. The analyses started in 2008, with the launching of some research projects regarding territorial management based on growth pole theory.

\section{MATERIALS AND METHODS}

The identifying of the environmental risk management's specificities at the level of development poles of regional importance was done by detailed analyses in Craiova, a representative town for the concentration of economic activities, which exerts a special pressure upon the natural environment.

The present study has given a special attention to international standards in the field of risk management, elaborated by The Institute of Risk Management (IRM), the Association of Insurance and Risk Managers (AIRMIC) and The National Forum for Risk Management in the Public Sector. According to these institutions, the complex process of risk management supposes following several well established stages (Fig.2): risk analysis, evaluation and reporting, decision, treatment and monitoring.

According to the standard Australian / New Zealand Standard (AS/NZS4360, 2001), the risk represents the possibility of an event to happen and consequently to induce effects upon the development objectives established at decisional level, whereas in a synthetical way the risk represents the effect of incertitude upon objectives (Fig.3). 


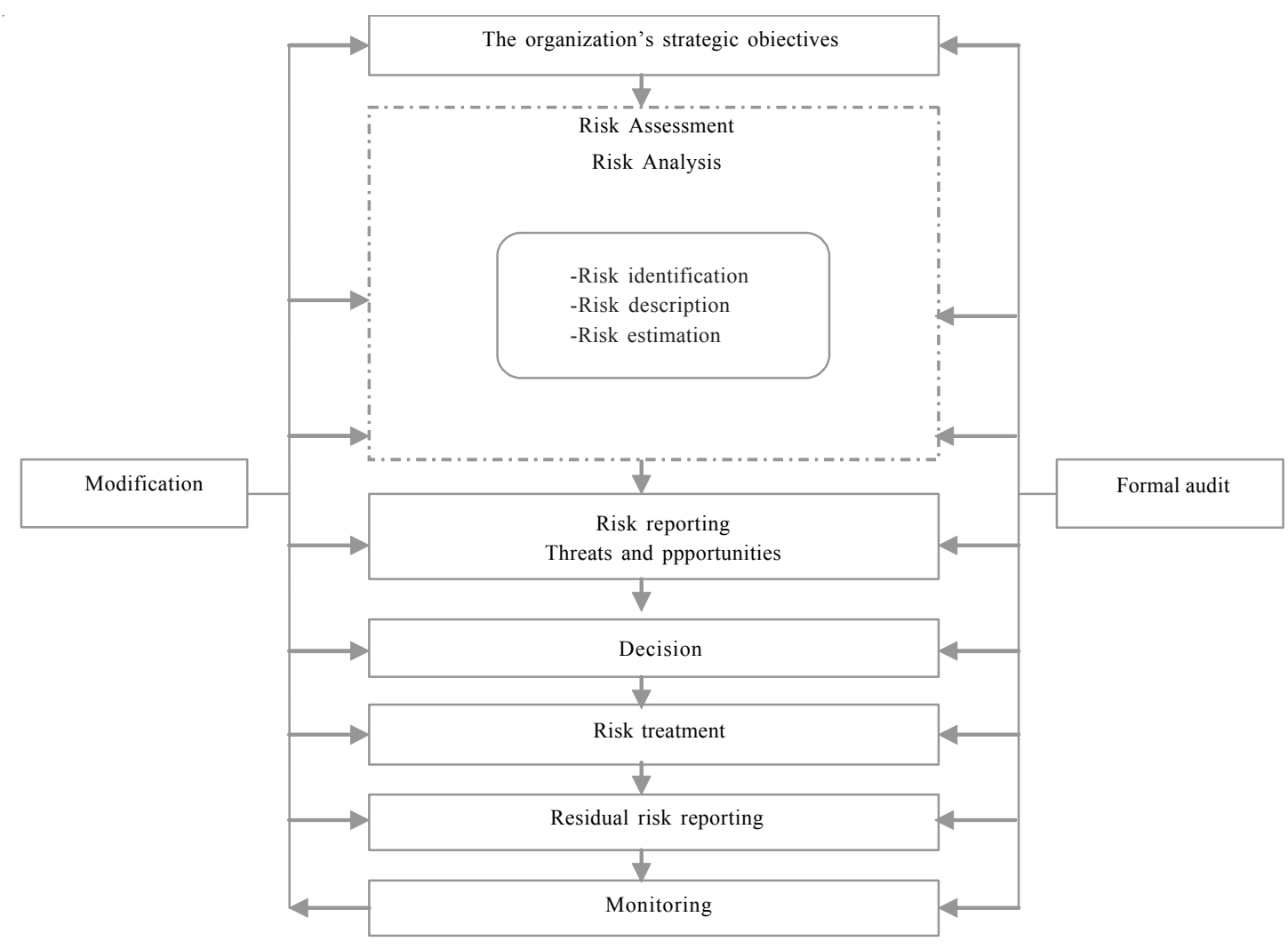

Fig. 2: The risk management process Source: Risk management standard, AIRMIC, ALARM, IRM (2002)

According to this standard, the risk management process unfolds in accordance with a series of principles, out of which the most important are: risk management creates and protects value, risk management is an essential part of the organising and decision processes (AS/NZS 4360, 2004).

The efficient environmental risk management is conditioned by a double approach: the existence of an efficient institutional system and the quantification of natural and anthropic risks. The natural risks management supposes to identify the measures necessary for the control of the unbalances form the natural subsystems, due to the human activities' pressure. The management of anthropic risks supposes the identifying and the attenuation of the unbalances determined by economic activities, as well as by important human flows oriented towards urban settlements of regional importance, appeared from the setting up of some large industrial platforms. Authors underline the delays in elaborating some strategies to protect the surface waters, delays that produce catastrophic effects on ecosystems. (Bebbington and Williams, 2008; Vinke-de Kruijf et al., 2009). The concentration of certain economic branches at these urban structures' level determined the pollution of ground waters, and this way specific measures for ensuring potable water for the population were necessary (Nouri et al., 2008; 2009).

The analysis of environmental risks was based upon identifying and quantification of numerous interventions, with different intensities, of the decision factors, which led to profound mutations in the proportion between the exploitation capacity $\left(\mathrm{E}_{\mathrm{c}}\right)$ and the development potential $\left(\mathrm{D}_{\mathrm{p}}\right)$, under the impulse of some violent interventions of the decision factors at long time intervals (Fig. 4).

\section{RESULTS AND DISCUSSION}

The analysis of the context of the environmental risk management was done following two directions: 


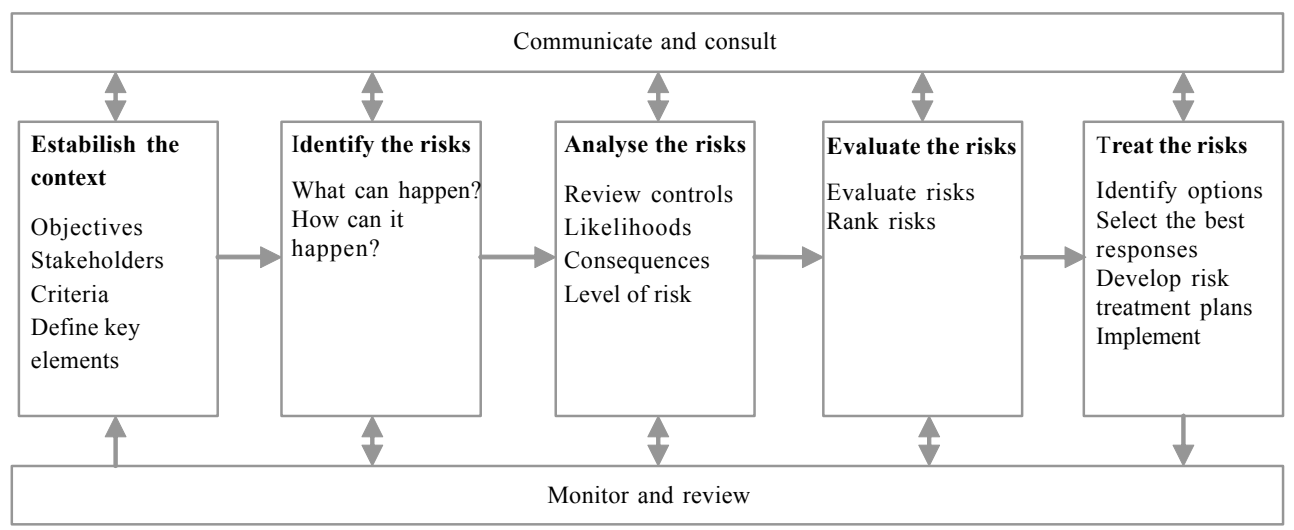

Fig. 3: The risk management process Source: Risk management standard, AS/NZS4360 (2004); (2001)

the institutional context and the judicial context. From the institutional point of view, the environmental risk management is done by the Town Hall in collaboration with the environment agency, all the decisions being approved by the Local Council, according to the provisions of the minister's order number 995/2006 and the Government Decision number 1.076/2004.

The European judicial context is ensured by a series of normative documents, the most important of which are the following: the Council's Directive 96/62/CEE regarding the assessment and management of surrounding air quality, the Council's Directive 1999/ 30/CE regarding the limit values for the sulphure dioxide, nitrogen dioxide, the suspension dusts/ powders and the plumb from the surrounding air (Decision 2001/44/ $\mathrm{CE}$, the European Parliament's and Council's Decision 2000/69/CE regarding the limit values for benzene and carbon dioxide from the surrounding air, the European Parliament's and Council's Decision 2002/3/CE regarding the ozone from the surrounding air, the Council's Decision 75/440/CEE regarding the surface waters' quality, the Council's Decision 80/68/CEE regarding the protection of ground waters against the pollution caused by certain dangerous substances, the Directive number 2006/12/CE regarding wastes.

The analyses regarding the environmental risk management within the development pole Craiova were accomplished on the basis of the observations registered by the Environment Protection Agency Dolj, in five observation points: work-station 1 (located in the area with the busiest traffic), work-station 2 (located in an area indirectly exposed to traffic and industrial pollution), work-station 3 (located in the areas exposed to the risk of chemical pollution and to intense traffic), work-station 4 (located on the industrial platform Isalnita, work-station 5 (located at a large distance from all pollution sources in the suburban area). The risk of air pollution is very high due to the concentration of

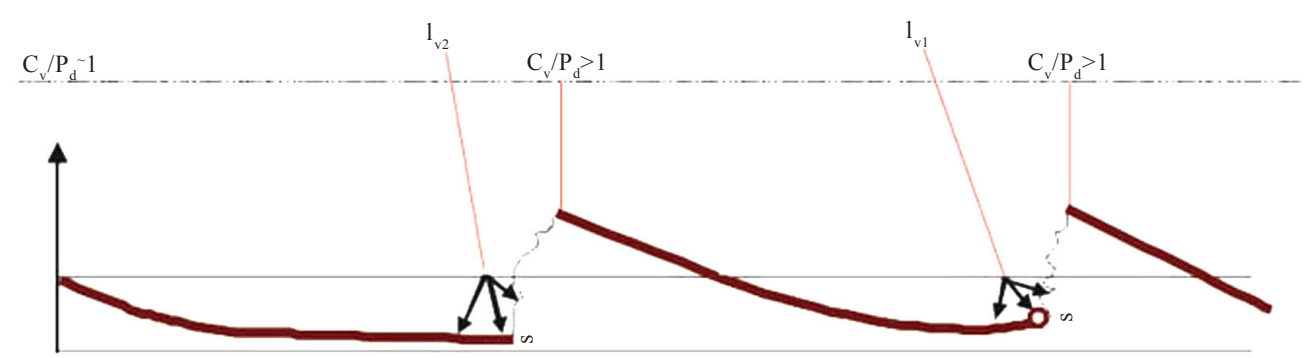

Fig. 4: Variation of the proportion between the exploitation capacity $\left(E_{c}\right)$ and the development potential $\left(D_{p}\right)$ Source: Ianos (2000) 
industrial units of national and regional importance, as well as due to the urban traffic. The area with the highest pollution degree is the western area, where the Industrial Platform Isalnita is situated (Fig. 5), where the chemical factory Doljchim and the steam power plant Isalnita are situated. In this area there is a high risk of pollution with sulphure's and nitrogen's oxides, carbon dioxide and white damp, as well as with organic volatile / essential compounds (Fig. 5). The functioning of some chemical factories nearby big cities contributes to a high risk of chemical pollution. The diminution of risks is conditioned by investments in the field of environment protection and building a monitoring system (Flynn et al., 1994; Cruz et al., 2006; Mishra et al., 2010; Peptenatu et al., 2010). Moreover, the permanent improvement of methodologies for analyzing the relationship between the economic and natural components is a major condition to elaborate some efficient development strategies (Mrkajic et al., 2010). The analyses done on the basis of the data registered by the Environment Protection Agency of Dolj underlines the pressure exerted by the more and more crowded traffic, due to the concentration of economic activities in the central areas and in the suburbs, along the main access roadways. In the central area (station 1), there are frequent exceeding at PM10 due to the frequent traffic jams (Table 1). In this area, the traffic intensity has increased twice during the last years, considering that infrastructure is the same from the communist period. There are to be added the emissions of $\mathrm{SO}_{2}$ due to pollutant emissions from the Energetic Complex Craiova, which comprises two steam power plants (SE Isalnita and SE Craiova II Simnic), which lead to frequent exceeding of the maximum admissible concentrations (Table 2). The intensification of the activity in these economic units led to a permanent increase of emissions of $\mathrm{SO}_{2}$ from $18333 \mathrm{t} /$ year, in the year 2000, to $21099 \mathrm{t} /$ year in the year 2008. Exceeding of this indicator appears at all stations for the monitoring of the air quality (Table 1).

The monitoring of material dusts PM10 is done around the clock at the traffic stations of the for Environment Protection Agency of Craiova, due to the frequent exceeding of the limit values (Table 2).

In the area of dumps Valea Manastirii and Isalnita, several excessive admisible limits of suspension dusts are registered, in windy conditions. The intense traffic on certain accessibility corridors (N. Titulescu, Calea Bucuresti and Decebal Boulevard) contributes to the exceeding of the maximum admissible limits. The risks diminution is conditioned by the construction of a system of traffic from the big cities' diffluence / fluidity, as well as the extension of the ring road with a sector able to take over the traffic from the southern area of the city. The industrial platforms Podari and East are less polluted, due to the restructuring of economic

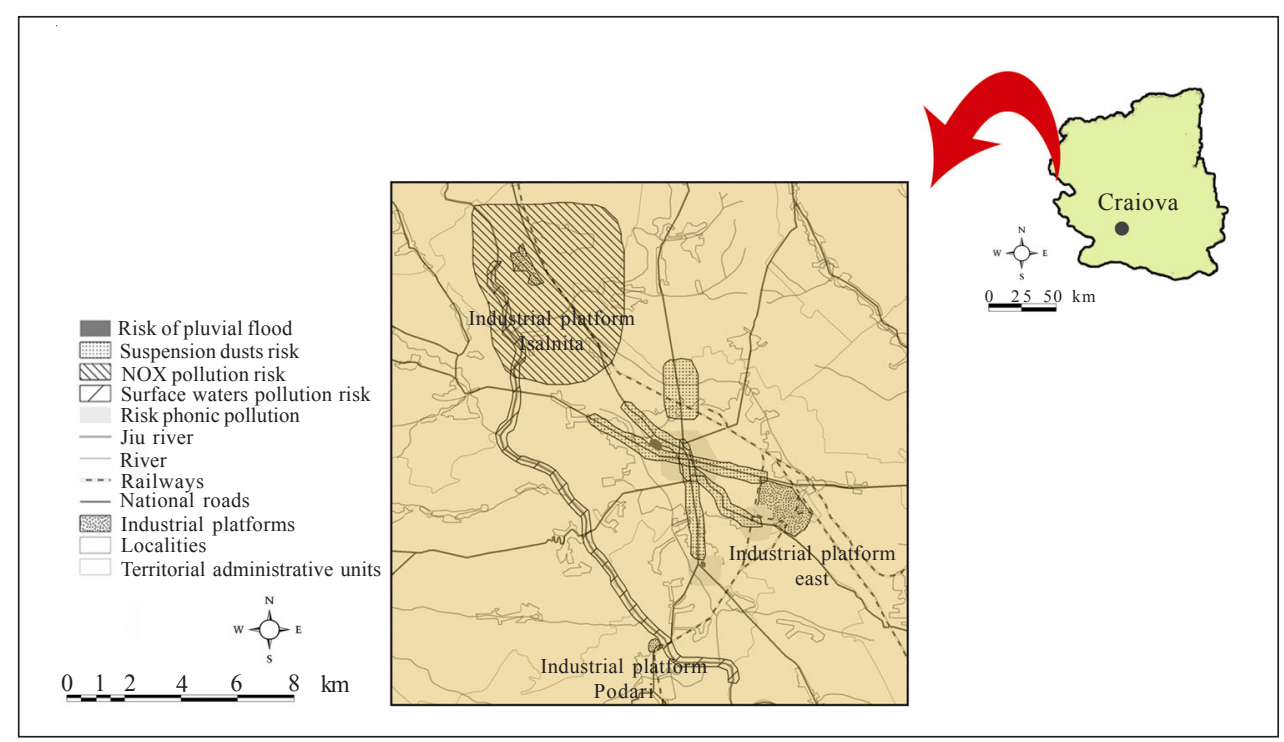

Fig. 5: Environmental risk in Craiova 


\section{Peptenatu et al.}

activities. The Industrial Platform South-East holds a series of enterprises (Electroputere, Reloc etc.), which contribute to the phonic pollution and to the emission of chemical polluants in the atmosphere.

The surface waters pollution risk is very high in the areas of the industrial platforms Isalnita and Podari, from where large quantities of industrial waters from the chemical factory Doljchim and the steam power plant Isalnita are overflown, as well as sewage, in the Jiu river. The quantifying of the pollution risk was done by comparing the physical-chemical analyses registered at the stations Isalnita and Podari. In Table 3 transition of surface waters from category I to category II of quality, due to large overflowing / overrunning of

Table 1: Air quality within the regional development pole Craiova (2007)

\begin{tabular}{|c|c|c|c|c|}
\hline \multirow{2}{*}{$\begin{array}{c}\text { Type } \\
\text { pollutant }\end{array}$} & \multirow{2}{*}{$\begin{array}{l}\text { Determination No. } \\
\text { (hourly average) }\end{array}$} & \multicolumn{2}{|c|}{ Concentration } & \multirow{2}{*}{$\begin{array}{c}\text { Frequency of } \\
\text { exceedings VL } \\
\text { conf.Ord. } \\
592 / 2002 \\
\end{array}$} \\
\hline & & Yearly & UM & \\
\hline $\mathrm{SO}_{2}$ & 6988, 303-daily & 16 & $\mu \mathrm{g} / \mathrm{m}^{3}$ & 0,04 and 0,33 \\
\hline NO & 6714 & 18 & $\mu \mathrm{g} / \mathrm{m}^{3}$ & $0 \%$ \\
\hline $\mathrm{NO}_{2}$ & 6686 & 33 & $\mu \mathrm{g} / \mathrm{m}^{3}$ & $0 \%$ \\
\hline NOx & 6686 & 60 & $\mu \mathrm{g} / \mathrm{m}^{3}$ & $0 \%$ \\
\hline $\mathrm{CO}$ & 6281 & 0,45 & $\mathrm{mg} / \mathrm{m}^{3}$ & $0 \%$ \\
\hline Benzen & 4776 & 2,3 & $\mu \mathrm{g} / \mathrm{m}^{3}$ & $0 \%$ \\
\hline Toluen & 4573 & 4,22 & $\mu \mathrm{g} / \mathrm{m}^{3}$ & \\
\hline O-xilen & 4432 & 1,15 & $\mu \mathrm{g} / \mathrm{m}^{3}$ & \\
\hline Etilbenzen & 4455 & 1,34 & $\mu \mathrm{g} / \mathrm{m}^{3}$ & \\
\hline m,p-xilen & 4562 & 4 & $\mu \mathrm{g} / \mathrm{m}^{3}$ & \\
\hline $\mathrm{PM}_{10}$ & 5230, 209-daily & 51 & $\mu \mathrm{g} / \mathrm{m}^{3}$ & 38 \\
\hline $\mathrm{SO}_{2}$ & 8188 356-daily & 17 & $\mu \mathrm{g} / \mathrm{m}^{3}$ & 0,097 and 0,54 \\
\hline NO & 8110 & 11 & $\mu \mathrm{g} / \mathrm{m}^{3}$ & \\
\hline $\mathrm{NO}_{2}$ & 8110 & 23 & $\mu \mathrm{g} / \mathrm{m}^{3}$ & $0 \%$ \\
\hline NOx & 8110 & 39 & $\mu \mathrm{g} / \mathrm{m}^{3}$ & \\
\hline $\mathrm{CO}$ & 8435 & 0,47 & $\mathrm{mg} / \mathrm{m}^{3}$ & $0 \%$ \\
\hline Benzen & 5413 & 3,5 & $\mu \mathrm{g} / \mathrm{m}^{3}$ & $0 \%$ \\
\hline Toluen & 5268 & 6 & $\mu \mathrm{g} / \mathrm{m}^{3}$ & \\
\hline O-xilen & 4075 & 3 & $\mu \mathrm{g} / \mathrm{m}^{3}$ & \\
\hline Etilbenzen & 4911 & 2 & $\mu \mathrm{g} / \mathrm{m}^{3}$ & \\
\hline m,p-xilen & 4824 & 6 & $\mu \mathrm{g} / \mathrm{m}^{3}$ & \\
\hline $\mathrm{SO}_{2}$ & 8015, 346-daily & 14 & $\mu \mathrm{g} / \mathrm{m}^{3}$ & 0,074 and 0,28 \\
\hline NO & 4104 & 24 & $\mu \mathrm{g} / \mathrm{m}^{3}$ & \\
\hline $\mathrm{NO}_{2}$ & 4104 & 34 & $\mu \mathrm{g} / \mathrm{m}^{3}$ & \\
\hline $\mathrm{NOx}$ & 4104 & 70 & $\mu \mathrm{g} / \mathrm{m}^{3}$ & \\
\hline $\mathrm{O} 3$ & 5800 & 81 & $\mu \mathrm{g} / \mathrm{m}^{3}$ & 0,63 \\
\hline $\mathrm{PM}_{10}$ & 6405, 253-daily & 55 & $\mu \mathrm{g} / \mathrm{m}^{3}$ & 44 (daily) \\
\hline $\mathrm{SO}_{2}$ & 7598 & 21 & $\mu \mathrm{g} / \mathrm{m}^{3}$ & 0,144 (hourly) \\
\hline & 323-daily & & & \\
\hline NO & 7338 & 7 & $\mu \mathrm{g} / \mathrm{m}^{3}$ & \\
\hline $\mathrm{NO}_{2}$ & 7186 & 18 & $\mu \mathrm{g} / \mathrm{m}^{3}$ & \\
\hline NOx & 7186 & 26 & $\mu \mathrm{g} / \mathrm{m}^{3}$ & \\
\hline $\mathrm{O}_{3}$ & 7693 & 42 & $\mu \mathrm{g} / \mathrm{m}^{3}$ & 0,22 \\
\hline $\mathrm{SO}_{2}$ & 7325, 308-daily & 18 & $\mu \mathrm{g} / \mathrm{m}^{3}$ & $\begin{array}{r}0,068 \text { and } 0,65 \\
\text { daily }\end{array}$ \\
\hline $\mathrm{NO}$ & 7277 & 5 & $\mu \mathrm{g} / \mathrm{m}^{3}$ & \\
\hline $\mathrm{NO}_{2}$ & 7177 & 14 & $\mu \mathrm{g} / \mathrm{m}^{3}$ & \\
\hline $\mathrm{NOx}$ & 7177 & 20 & $\mu \mathrm{g} / \mathrm{m}^{3}$ & \\
\hline $\mathrm{CO}$ & 4059 & 0,3 & $\mathrm{mg} / \mathrm{m}^{3}$ & \\
\hline $\mathrm{O}_{3}$ & 7559 & 62 & $\mu \mathrm{g} / \mathrm{m}^{3}$ & 8 \\
\hline $\mathrm{PM}_{10}$ & 7351, 295-daily & 32 & $\mu \mathrm{g} / \mathrm{m}^{3}$ & 14,57 (daily) \\
\hline
\end{tabular}

The Environment Protection Agency Dolj Report (2008) 
Int. J. Environ. Sci. Tech., 8 (4), 737-746, Autumn 2011

Table 2: The number of overtakings of the limit values plus the margin of tolerance

\begin{tabular}{|c|c|c|c|c|c|c|c|c|c|}
\hline \multirow[t]{2}{*}{ Station } & \multicolumn{9}{|c|}{ Pollutant emissions } \\
\hline & $\mathrm{SO}_{2}$ & $\overline{\mathrm{NO}_{2}}$ & $\mathrm{NO}_{\mathrm{X}}$ & $\mathrm{PM}_{10}$ & $\mathrm{PM}_{25}$ & PB & $\mathrm{C}_{6} \mathrm{H}_{6}$ & $\mathrm{CO}$ & $\mathrm{O}_{3}$ \\
\hline 1 & 9 & - & - & 80 & - & - & - & - & - \\
\hline 2 & 10 & - & - & - & - & - & - & - & - \\
\hline 3 & 5 & - & - & 111 & - & - & - & - & - \\
\hline 4 & 18 & - & - & - & - & - & - & - & - \\
\hline 5 & 3 & - & - & 43 & - & - & - & - & - \\
\hline
\end{tabular}

The Environmental Protection Agency Dolj Report (2008)

polluted waters can be noticed (Table 3 ).

The ground waters pollution risk is present on large areas on the industrial platforms and their surrounding areas. The area with the highest pollution risk is situated in the region of the Industrial Platform Isalnita, where, according to physical-chemical analyses for monitoring the pollution of phreatic waters from the area of steam power plant Craiova II's ash deposits, in their neighbouring area, phreatic waters are polluted with sulphates and iron, with high values at permanent residue and basic $\mathrm{pH}$. The analyses of the County Public Health Directorate, according to the law of potable water no $458 / 2002$, emphasized several areas around Craiova where nitrates exceed the maximum admissible concentration (CMA): Bratovoiesti-96 mg/L, Breasta- $80 \mathrm{mg} / \mathrm{L}$, Ghercesti-85 mg/L, Malu Mare-155 mg/L, Podari -163 $\mathrm{mg} / \mathrm{L}$, Cosoveni-61 mg/L, Simnic-124 mg/L. These overflows are determined by the long action of impact factors, represented by the functioning of some industrial installations with noxious emissions, as well as by depositing important amounts of industrial wastes.

The risk of pluvial flood is present in several sectors, where during heavy rains the canalisation can not go through waters debit, generating important damages. There are frequent floods in the areas: Brestei-Cap-de-Linie Street and the area of side streets, Brestei Street (crossroads with Pelendava),
Romanescu District (the area of the streets Odessa, Homer, Petrila) and the industrial Area West (Prefabricate, Coop. Oltenia) (The Environment Protection Agency Dolj Report, 2008).

The risk of soil pollution is determined by the storing of some industrial wastes in conditions whic are inappropriate. The soil samples gathered from the area of the Ecological Deposit of Urban Wastes Mofleni, the cinder and ash deposits of S.C. Complex Energetic Craiova S.E. Isalnita and S.C. Complex Energetic Craiova S.E. Craiova II, highlighted the excess of the content of heavy metals $(\mathrm{Cu}, \mathrm{Pb}, \mathrm{Zn}$ and Cd) (The Environment Protection Agency Dolj Report, 2008).

Nearby steam power plants the soil was periodically affected, partially and insignificantly with dust and powders (cinders and ash) directly, drawn from the depositing dumps in the drought and strong winds period.

The risk of phonic pollution is determined by the concentration of traffic on certain accessibility corridors and in the area of industrial platforms. The areas most exposed to phonic pollution risk (with values between $68,65 \mathrm{~dB}$ and $72,17 \mathrm{~dB}$ ) are the entrances in towns from Filiasi, Bucharest, Calafat

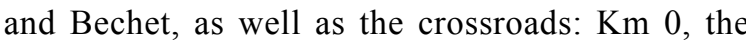
University, PECO Severinului, RA Station, Pasaj Electro, Regionala CFR, Rocada Raului. Industrial activities contribute to overflows of noise limits on

Table 3: Jiu water quality in the urban space

\begin{tabular}{|c|c|c|c|c|c|c|c|c|c|c|}
\hline \multirow{3}{*}{ Station } & \multirow{3}{*}{$\begin{array}{l}\text { Quality } \\
\text { category }\end{array}$} & \multicolumn{9}{|c|}{ Annual average } \\
\hline & & \multirow{2}{*}{$\mathrm{pH}$} & $\mathrm{O}_{2} \operatorname{diz}$ & $\mathrm{RF}$ & $\mathrm{Cl}^{-}$ & $\mathrm{NH}_{4}$ & $\mathrm{CCO}-\mathrm{Mn}$ & $\mathrm{CBO}_{5}$ & $\mathrm{NO}_{3}$ & \multirow{2}{*}{$\mathrm{NO}_{2}^{-}$} \\
\hline & & & $\mathrm{mg} / \mathrm{L}$ & $\mathrm{mg} / \mathrm{L}$ & $\mathrm{mg} / \mathrm{L}$ & $\mathrm{mg} / \mathrm{L}$ & $\mathrm{mg} / \mathrm{L}$ & $\mathrm{mg} / \mathrm{L}$ & $\mathrm{mg} / \mathrm{L}$ & \\
\hline Işalnița & I & 7,6 & 9,3 & 231 & 34 & 0,4 & 5,3 & 2,7 & 3,6 & 0,01 \\
\hline Podari & II & 7,7 & 8 & 343 & 46 & 0,7 & 6,6 & 3,5 & 4,4 & 0,035 \\
\hline
\end{tabular}

The Environment Protection Agency Dolj Report (2008) 
the Industrial Platform Isalnita (60-70 dB) and the Industrial Platform east, where activities from the factories Electroputere, IUG, Tufon and MAT generate noise continuously.

The risk of pollution with the cities' wastes is determined by the system of gathering the city's wastes, which does not have installations for wastes' treatment before depositing (the Deposit Mofleni), leading to the pollution on large areas with unpleasant smells. Also, the winds carry light materials and infiltrations of dump towards the ground waters, thus leading to their pollution (The Environment Protection Agency Dolj Report, 2008).
The building of the management model of environmental risks supposes their classification, taking into account a series of criteria, on the basis of which there were established the action priorities, with the purpose of reducing the unbalances from the environment.

The environmental risk classification criteria consists of the impact upon human health (appreciated with average 3) and the restrictions for development (average 2), criteria which establish the action priorities for an optimate management of environmental risks. Each problem which was identified was given a score from 1 (the lowest) to 10

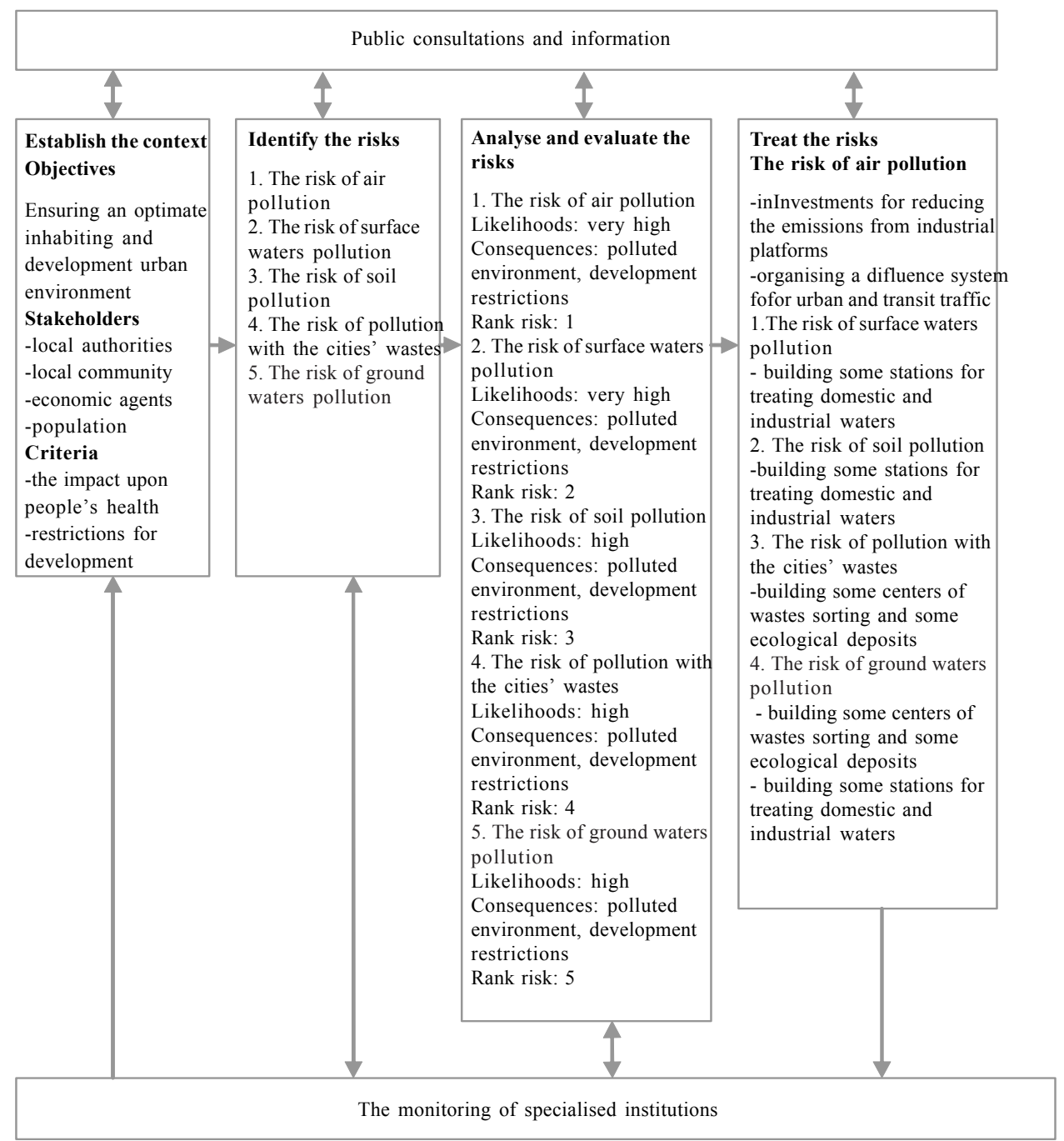

Fig. 6: The specificity of the environment management model in the development pole Craiova 
(the highest). Starting from the aggregated values, the management model of the environment in Craiova was filled in for each stage of the management process (Fig. 6).

\section{CONCLUSION}

The particularity of the evolution of development of towns with over 300000 inhabitants from Romania is given by the important role they have within the coordination of regional polycentric networks and real regional economic capitals. This status they held, both during the communist period and at present, made economic activities exceed the adaptation capacity of the other components of the territorial system.

The unbalances appeared within the functional relationships between the system's components, were emphasized by the intensity of decisional impulses in short intervals of time, which contributed to the apparition of some strong breaches between the Exploitation capacity (Ec) and the Development potential $\left(\mathrm{D}_{\mathrm{p}}\right)$.

The detailed analyses, done at the level of a representative town from this category, show the fact that the strongest effects are felt today at the level of natural environment's components, strongly affected by rapid industrialization and spectacular growth of the inhabitants number, both aspects contributing to the degradation of natural environment.

Exceeding the maximum admitted limits for certain indicators, and the higher and higher pressure upon accesibility corridors in these towns, will lead, in perspective, to voluntary restrictions of development or restrictions imposed by the decision factors, in order to reduce these unbalances.

\section{AKNOWLEDGEMENTS}

The methodology used in this article was elaborated in some research project Territorial Management Based on Growth Poles Theory (UEFICSU-PNII-Idei, 1950) and the strategic grant POSDRU/89/1.5/S/58852, Project, Postdoctoral programme for training scientific researchers cofinanced by the European Social Found within the Sectorial Operational Program Human Resources Development 2007-2013.

\section{REFERENCES}

AS/NZS4360, (2001). Risk management. Standards Australia/ Standards New Zealand, Sydney/Wellington. (11 pages).

Babut, G.; Moraru, R., (2006). Cadrul general al managementului riscului de mediu, Buletinul, AGIR nr. 3/2006, 103-107
(5 pages).

Bebbington, A.; Williams, M., (2008). Water and Mining Conflicts in Peru, Mountain. Res. Develop., 28 (3-4), 190195 (6 pages).

Beer, T., (2006). Ecological Risk Assessment and Quantitative Consequence Analysis. Human and Ecological Risk Assessment. An. Int. J., 12 (1), 51-65 (15 pages).

Braghinã, C.; Peptenatu, D.; Constantinescu, ${ }^{a}$ t.; Pintilii, R. D.; Drãghici, C., (2010). The pressure exerted on the natural environment in the open pit exploitation areas in Oltenia. Carpath. J. Earth Environ. Sci., 5 (1), 33 - 40 (8 pages).

Chien, M. K.; Shih, L. H., (2007). An empirical study of the implementation of green supply chain management practices in the electrical and electronic industry and their relation to organizational performances. Int. J. Environ. Sci. Tech., 4 (3), 383-394 (12 pages).

Choi, Y.; Lee, E. Y., (2009). Optimizing Risk Management for the Sustainable Performance of the Regional Innovation System in Korea through Metamediation, Human and Ecological Risk Assessment. An. Int. J., 15 (2), 270-280 (11 pages).

Cruz,A. M.;Steinberg,L. J.;Veterre-Arellano,A. L., (2006). Emerging issues for natech disaster risk management in Europe. J. Risk Res., 9 (5), 483-501 (19 pages).

Fekete, J. G., (2006). Education, research and development tasks of environmental protection. Carpath. J. Earth Environ. Sci., 1 (2), 5-12 (8 pages).

Flynn, J.; Slovic, P.; Mertz, C. K., (1994). Gender, race, and perception of environmental health risks. Risk Analys., 14 (6), 1101-1108 (8 pages).

Gavrilescu, M., (2009). Behaviour of persistent pollutants and risks associated with their presence in the environment integrated studies. Environ. Engin. Manage. J., 8 (6), 15171531 (15 pages).

Hooghe, L.; Marks, G., (2001). Multi-Level Governance and European Integration, Lanham, MD, Rowman and Littlefield, 1-24 (24 pages).

Ianos, I., (2000), Teoria sistemelor de $a^{\circ}$ ezãri umane, Editura Tehnicã, Bucure ${ }^{\circ}$ ti.

Ianos, I.; Peptenatu, D.; Zamfir, D., (2009). Respect for environment and sustainable development. Carpath. J. Earth and Environ. Sci., 4 (1), 81-93

(13 pages).

Mishra, R. K.; Parida, M.; Rangnekar, S., (2010). Evaluation and analysis of traffic noise along bus rapid transit system corridor. Int. J. Environ. Sci. Tech., 7 (4), 737-750 (14 pages).

Mrkajic, V.; Stamenkovic, M.; Males, M.; Vukelic, D.; Hodolic, J., (2010). Proposal for reducing problems of the air pollution and noise in the urban environment. Carpath. J. Earth and Environ. Sci., 5 (1), 49 - 56 (8 pages).

Nouri, J.; Mansouri, N. ; Abbaspour, M.; Karbassi, A. R.: Omidvari, M., (2011). Designing a developed model for assessing the disaster induced vulnerability value in educational centers. Safety Sci., 49 (5), 679-685 (7 pages).

Nouri, J.; Fatemi, M. R.; Danekar, A.; Fahimi, F. G.; Karimi, D., (2009). Determination of environmentally sensitive zones along Persian Gulf coastlines through geographic information system. J. Food Agr. Environ., 7 (2), 718725 (8 Pages).

Nouri, J.; Danehkar, A.; Sharifipour, R., (2008). Evaluation of ecotourism potential in the northern coastline of the 


\section{Peptenatu et al.}

Persian Gulf. Environ. Geo., 55 (3), 681-686 (6 pages). Peptenatu, D.; Pintilii, R. D.; Draghici, C.; Stoian, D., (2010). Environmental pollution in functionally restructured urban areas: case study - the city of Bucharest, Iran. J. Environ. Health Sci. Eng., 7 (1), 87-96 (10 pages).

Pollack, M., (1994). Creeping competence. The expanding agenda of the European Community. J. Eur. Public Policy, 14 (2), 95-145 (56 pages).

Risk Management Standard, (2002). AIRMIC, ALARM, IRM, (17 pages).

Robu, B.; Macoveanu, M., (2009). Strategic environmental assessment for plans, programs, policies in Romania: multicriterial method. Environ. Engin. Manage. J., 8 (6), 14511456 (6 pages)

Standartds Australia and Stansards New Sealand, HB 436, (2004). Risk management Guidelines: Companion to AZ/ NZS 4360:2004, Sydney, NSW (11 pages).

Szigethy, E., (2007). Environment and earth sciences in communication and media in Hungary. Carpath. J. Earth Environ. Sci., 2 (1), 5-8 (4 pages).

Tehrani, S. M.; Karbassi, A. R.; Ghoddosi, J.; Monavvari, S. M.; Mirbagheri, S. A., (2009). Prediction of energy consumption and urban air pollution reduction in eshopping. J. Food Agr. Environ., 7 (3-4), 898-903 (5 pages).

Tehrani, S. M.; Karbassi, A. R.; Monavari, S. M.; Mirbagheri, S. A., (2010). Role of E-shopping Management Strategy in Urban Environment. Int. J. Environ. Res., 4 (4), 681690 (10 pages).

The Environment Protection Agency Dolj Report, (2008). (192 pages).

Vinke-de Kruijf, J.; Dinica, V.; Denie, C. M.; Augustijn, B., (2009). Reorganization of water and waste water management in Romania: from local to regional water governance. Environ. Engin. Manage. J., 8 (5), 1061-1071 (11 pages).

AUTHOR (S) BIOSKETCHES

Peptenatu, D., Ph.D., Lecturer, Department of Human and Economic Geography and Researcher at The Interdisciplinary Center for Advanced Researches on Territorial Dynamics, University of Bucharest, Romania. Email: peptenatu@yahoo.fr

Pintilii, R. D., Ph.D., Researcher, The Interdisciplinary Center for Advanced Researches on Territorial Dynamics, University of Bucharest, Romania. Email: pinty_ro@yahoo.com

Draghici, C., Ph.D., Researcher in The Interdisciplinary Center for Advanced Researches on Territorial Dynamics, University of Bucharest, Romania. Email: cristi7772001@yahoo.com

How to cite this article: (Harvard style)

Peptenatu, D.; Pintilii, R. D.; Draghici, C., (2011). Environmental risk management of urban growth poles regarding national importance. Int. J. Environ. Sci. Tech., 8 (4), 737-746. 